\title{
Results of Scoping Tests Examining the Effects of Gilsulate, Aluminum Silicate and Defoamers on the Operation of Conductivity Level Probes
}

by

\author{
R. F. Swingle
}

Westinghouse Savannah River Company

Savannah River Site

Aiken, South Carolina 29808

This paper was prepared in connection with work done under the above contract number with the U.S. Department of Energy. By acceptance of this paper, the publisher and/or recipient acknowledges the U.S. Government's right to retain a nonexclusive, royalty-free license in and to any copyright covering this paper, along with the right to reproduce and to authorize others to reproduce all or part of the copyrighted paper. 


\section{DISCLAIMER}

This report was prepared as an account of work sponsored by an agency of the United States Government. Neither the United States Government nor any agency thereof, nor any of their employees, makes any warranty, express or implied, or assumes any legal liability or responsibility for the accuracy, completeness, or usefulness of any information, apparatus, product, or process disclosed, or represents that its use would not infringe privately owned rights. Reference herein to any specific commercial product, process, or service by trade name, trademark, manufacturer, or otherwise does not necessarily constitute or imply its endorsement, recommendation, or favoring by the United States Government or any agency thereof. The views and opinions of authors expressed herein do.not necessarily state or reflect those of the United States Government or any agency thereof.

This report has been reproduced directly from the best available copy.

Available to DOE and DOE contractors from the Office of Scientific and Technical Information, P. O. Box 62, Oak Ridge, TN 37831; prices available from (423) 576-8401.

Available to the public from the National Technical Information Service, U. S. Department of Commerce, 5285. Port Royal Road, Springfield, VA 22161. 


\section{DISCLAIMER}

Portions of this document may be illegible in electronic image products. Images are produced from the best available original document. 

Keywords: Tank Farm
Conductivity Probes
Gilsulate
Defoamers

Retention Time: Permanent

Results of Scoping Tests Examining the Effects of Gilsulate, Aluminum Silicate and Defoamers on the Operation of Conductivity Level Probes

R. F. Swingle

Publication Date: November 12, 1998

Westinghouse

Savannah River Company

Alken, SC 29808 


\section{SUMMARY}

Scoping tests have been completed examining the effects of Gilsulate, sodium aluminum silicate, and some organic materials on the operation of tank level conductivity probes. The tests indicate that Gilsulate does float on top of water or salt solution and in sufficient quantity can interfere with the operation of tank level conductivity probe. Quantification of the amount required to interfere with probe operation is difficult since the Gilsulate floats and does not necessarily disperse evenly over the surface of the liquid.

An attempt was made to crystallize sodium aluminum silicate, a material similar to the majority constituent of Gilsulate that is found in the Tank Farm, to determine whether it could interfere with conductivity probe operation. However, all crystals precipitated to the bottom of the container and did not interfere with the probe.

Dow Corning $\mathrm{H}-10$ antifoaming agent was not found to interfere with the operation of the conductivity probe in any quantity tested up to a depth of $1.7 \mathrm{~mm}$. Dow Corning Antifoam 544 up to a depth of 0.2 $\mathrm{mm}$ did not interfere with operation of the probe. However, with $\sim 1.6 \mathrm{~mm}$ of Antifoam 544 on the surface of the salt solution, the conductivity probe did not register.

The effect of a mixture of 30\% tri-n-butyl phosphate (TBP) and 70\% n-paraffin was also studied. As long as the surface of the salt solution was not completely covered, there was no interference with the operation of the probe. However, the probe would not register contact with organic alone when the surface of the liquid was completely covered with the organic mixture. Once the probe was lowered through the organic phase and the aqueous phase was contacted, the probe registered a positive contact.

Therefore the probes can still be used to determine the 24-inch level below the organic layer for transfer operations to avoid carry over of organics.

\section{INTRODUCTION}

High Level Waste Management Engineering personnel noted recently that Gilsulate, an insulating material used in the Tank Farm, could interfere with the operation of conductivity level probes found in the leak collection boxes in the Tank Farm. These conductivity probes alert personnel to the collection of liquid in the leak collection boxes. The source of this liquid could be either leakage concentrated supernate material from the gravity drain lines or leakage of water from the environment into the gravity drain line jacket. High Level Waste Management Engineering personnel requested that SRTC examine the effects of Gilsulate on the operation of the conductivity probe [1]. Because the sodium aluminum silicate material which recently crystallized in an evaporator system drain line was similar in composition to the majority constituent of Gilsulate, it was also requested that this material be examined. Since antifoamers and organic materials might also be found in the tank farm, this study included the impact of those materials on conductivity probe operation. This report documents the results of scoping studies completed to examine the effect of those materials on conductivity probes. 


\section{DISCUSSION}

Concentrated salt solution from the Tank Farm is drained to waste tanks through underground piping referred to as gravity drain lines. These lines are jacketed to collect either leakage out from the primary line or inleakage from the environment to the jacket. The jacketing pipe in turn drains to a leak detection box where any accumulated liquid is detected with a conductivity probe. The jacketing pipe is insulated with Gilsulate, a powdered mixture of sodium potassium aluminum silicate and calcium carbonate with proprietary additives that make the material hydrophobic. Should Gilsulate leak into the jacket piping and accumulate in the leak detection box, there is a concern that the Gilusulate could interfere with conductivity probe operation thereby reducing or eliminating leak detection capability.

This study was also concerned with the operation of conductivity probes in the waste tanks where organic material is the main concern. Organic laden waste, primarily TBP/n-paraffin, from F-canyon enters F Tank Farm via F Pump Tank 3 (FPT3) and is stored in Tank 33F, the designated receiver tank. Tank 33F feeds Tank 26F, the 242-16F Evaporator feed tank. Both Tanks $26 \mathrm{~F}$ and 33F are designated as "organic" tanks. Waste from H Canyon enters the H Tank Farm via H Pump Tank 5 (HPT5) and is stored in Tank $43 \mathrm{H}$, which is therefore also designated an organic tank. Tank $43 \mathrm{H}$ is the feed tank to the $2-\mathrm{H}$ evaporator. The Tank Farm is required to limit transfers from organic tanks by preventing the floating organic layer from getting within 24 inches of the transfer steam jets. The level of the aqueous phase and by inference the floating organic layer is verified through use of conductivity probes. Therefore, it is important to understand the dynamics of probe responses with in the pertinent organic liquids.

\section{Test Method}

SRTC initially examined the resistance changes caused by the addition of Gilsulate and other materials to the surface of water and salt solutions. The nominal depth of the materials added was determined.by taking the ratio of the volume of material added to the surface area of the liquid. High Level Waste Engineering personnel indicated that a resistance of $\sim 0.6 \mathrm{M} \Omega$ was the point above which the conductivity probe had difficulty operating. In these tests, a multimeter on the resistance setting was connected to on one end to the metal (stainless steel) beaker containing the liquid and on the other end to a stainless steel probe that could then be lowered into the liquid. Many readings obtained using this method were above $0.6 \mathrm{M} \Omega$ and were considered inconclusive and therefore a Gempack test circuit was borrowed from High Level Waste Management to complete the tests. This circuit indicates a closed circuit resulting from a conductive liquid between the conductivity probe and the metal vessel. For these tests, the Gempack test circuit is connected to the metal test vessel (a stainless steel beaker) and the conductivity probe. When the aqueous solution in the beaker contacts the probe, the circuit is closed illuminating an indicator light in the Gempack test circuit. The probe was tested at 3 levels of insertion: tip just touching surface (Tip), $\sim 1 / 8$ inch submerged (End) and $\sim 3 / 4$ inches submerged (Notch). The $1 / 8$ and $3 / 4$ inch submersion correspond to the boundaries of a notch in the end of the probe. Figures 1,2 and 3 show these insertion levels. 
WSRC-TR-98-00408

Revision 0

Page 4 of 16

November 12, 1998

Figure 1. Probe with Tip Just Touching Surface (Tip)

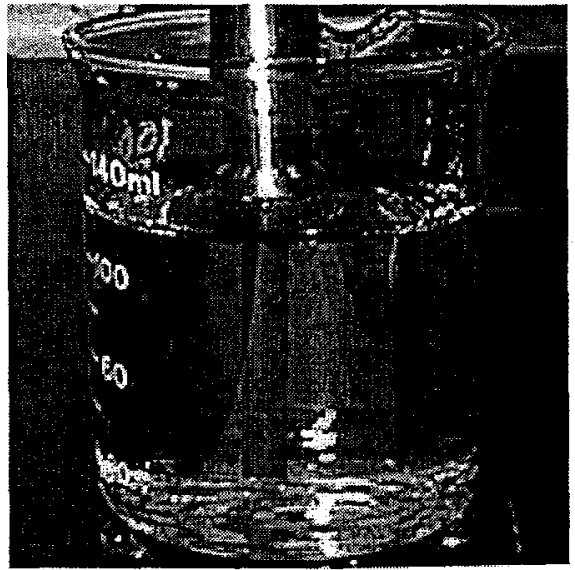

Figure 2. Probe with $\sim 1 / 8$ Inch Submerged (End)

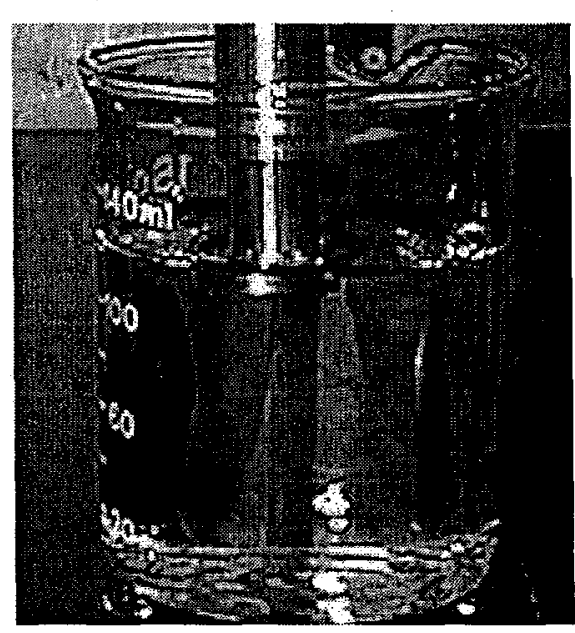


Figure 3. Probe with $\sim 3 / 4$ Inches Submerged (Notch)

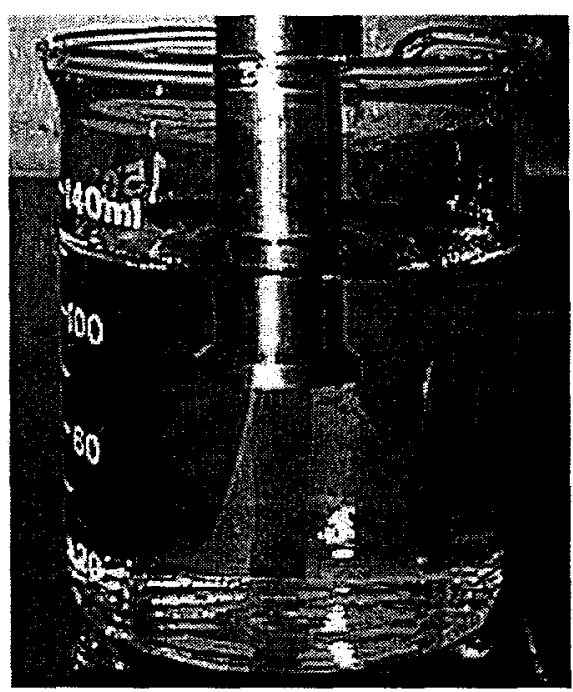

Tests were conducted using tap water, simulated High Level Waste salt solution or Tank $43 \mathrm{H}$ salt solution. Compositions are given in Table 1. Successively larger amounts of the material being tested (e.g., Gilsulate and Dow Corning $\mathrm{H}-10$ ) were added to the surface of the aqueous liquid and the probe operability checked.

\section{Table 1. Composition of Salt Solutions}

\begin{tabular}{|c|c|c|c|c|}
\hline \multirow[b]{2}{*}{ Component } & \multicolumn{4}{|c|}{ Concentration (M) } \\
\hline & $\begin{array}{c}\text { Simulated High } \\
\text { Level Waste } \\
\text { Salt Solution }\end{array}$ & $\begin{array}{c}\text { Tank 43H Salt } \\
\text { Solution }\end{array}$ & $\begin{array}{l}10 \mathrm{M} . \mathrm{Na}^{+} \text {with } \\
\text { Aluminum } \\
\text { Silicate }\end{array}$ & $\begin{array}{l}3 \mathrm{M} \mathrm{Na}^{+} \text {with } \\
\text { Aluminum } \\
\text { Silicate }\end{array}$ \\
\hline $\mathrm{NaOH}$ & 8.00 & 7.22 & 5.80 & 1.50 \\
\hline $\mathrm{NaAl}(\mathrm{OH})_{4}$ & - & 0.56 & 0.50 & 0.50 \\
\hline $\mathrm{NaNO}_{3}$ & 0.37 & 1.68 & 2.50 & 0.80 \\
\hline $\mathrm{NaNO}_{2}$ & 1.23 & 1.50 & 1.00 & 0.20 \\
\hline $\mathrm{Na}_{2} \mathrm{CO}_{3}$ & - & 1.14 & - & - \\
\hline $\mathrm{Na}_{2} \mathrm{SO}_{4}$ & - & 0.011 & - & - \\
\hline $\mathrm{Na}_{3} \mathrm{PO}_{4}$ & - & 0.038 & - & - \\
\hline $\mathrm{Na}_{2} \mathrm{SiO}_{3}$ & - & - & 0.10 & 0.10 \\
\hline Total Sodium & 9.60 & 13.4 & 10.00 & 3.20 \\
\hline
\end{tabular}


In the case of the sodium aluminum silicate tests, a solution was prepared from which the sodium aluminum silicate could be crystallized. The probe was submerged up to $3 / 4$ inch in the salt solution and crystals were allowed to form. The probe's operability was checked using the multimeter.

Results obtained using the multimeter varied greatly and proved inconclusive when compared to the $\sim 0.6$ $M \Omega$ value indicated by HLWME personnel. However, in some cases, the multimeter gave an infinite resistance. It is believed that the infinite resistance reading is probably more representative of the failure of the conductivity probe than a $0.6 \mathrm{M} \Omega$ reading.

As a result of the inconclusive nature of the multimeter tests, a Gempack circuit was borrowed from HLWM personnel to conduct further tests. The Gempack circuit gives a more conclusive indication of closed circuit with the illumination of a signal light. Occasionally, the relay in the circuit will chatter indicating a closed circuit with a higher than normal resistance.

\section{Results}

\section{Gilsulate Tests}

When Gilsulate was added to the surface the aqueous phase, it tended to gather together, not covering the surface uniformly. Figure 4 shows an example of test with a smaller amount of Gilsulate that did not completely cover the surface. Figure 5 shows an example of a test with a larger amount of Gilsulate in which the surface was nearly completely covered. Tests with the conductivity probe were conducted in duplicate with the probe being lowered into an area of low Gilsulate concentration and then into an area of high Gilsulate concentration. It was noted in some tests that the Gilsulate tended to move out from under the probe. The multimeter tests indicated no problems until $\sim 0.04 \mathrm{~g} / \mathrm{cm}^{2}$ of Gilsulate were added, assuming that over ranged is indicative of a problem. The probe did not function at all with this level of Gilsulate. Results of the Gilsulate-tap water tests conducted using the multimeter are given in Table 2. Results of the Gilsulate-Simulated High Level Waste salt solution tests are given in Table 3. 
WSRC-TR-98-00408

Revision 0

Page 7 of 16

November 12, 1998

Figure 4. Gilsulate Partially Covering the Surface

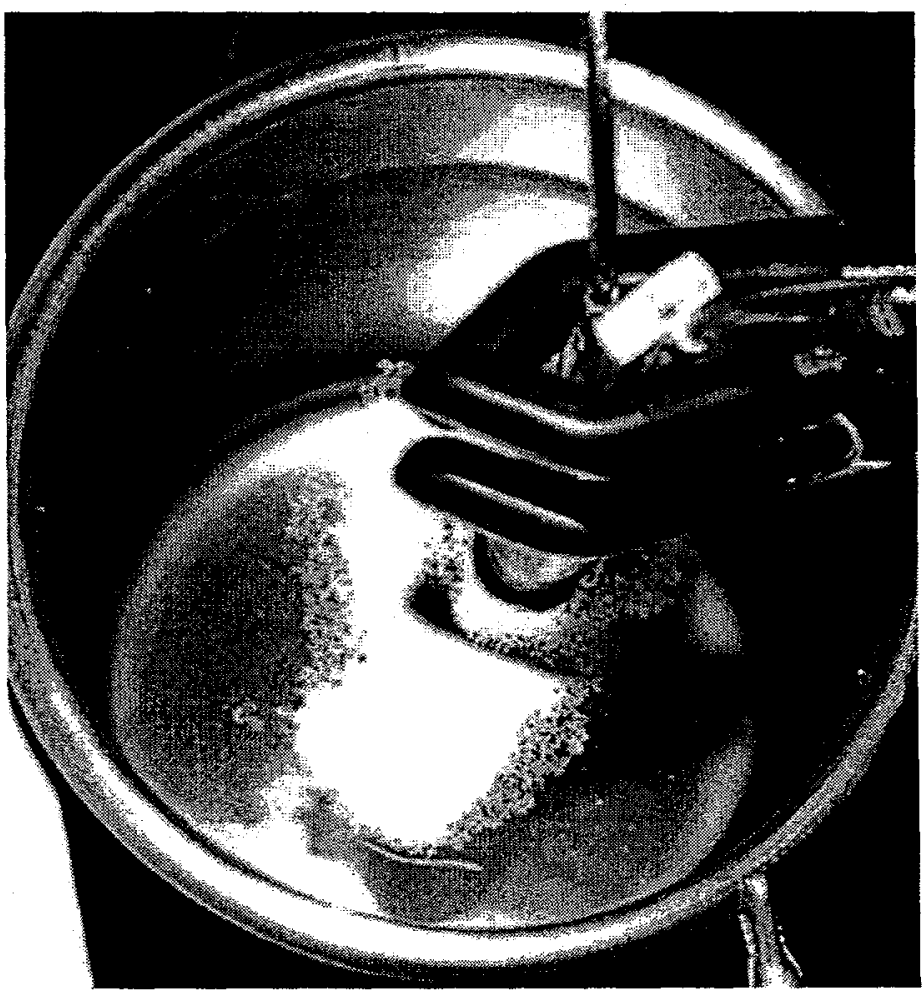

Figure 5. Gilsulate Nearly Completely Covering the Surface

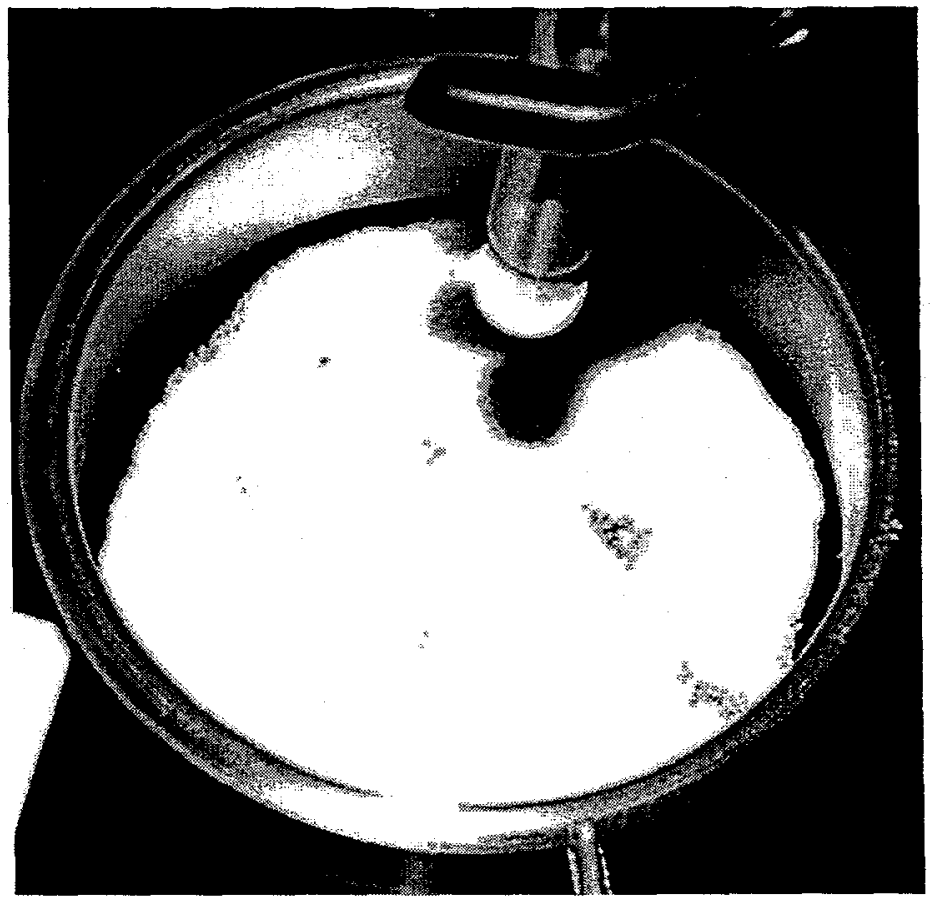


Table 2. Results of Gilsulate-Water Conductivity Probe Tests Using the Multimeter

\section{Solution}

Tap Water (no Gilsulate)

Tap Water (with $0.0001 \mathrm{~g} / \mathrm{cm}^{2}$

Gilsulate)

Tap Water (with $0.00045 \mathrm{~g} / \mathrm{cm}^{2}$

Gilsulate)

Tap Water (with $0.00087 \mathrm{~g} / \mathrm{cm}^{2}$

Gilsulate)

Tap Water (with $0.0042 \mathrm{~g} / \mathrm{cm}^{2}$

Gilsulate)

Tap Water (with $0.0085 \mathrm{~g} / \mathrm{cm}^{2}$ Gilsulate)

Tap Water (with $0.042 \mathrm{~g} / \mathrm{cm}^{2}$ Gilsulate)

\section{Tip}

4.15

4.63

3.62

3.51

2.47

\section{Resistance (M-ohms)}

End

2.51

3.20

Notch

1.83

.20

2.85

6.83

3.49

2.56

4.62

10.4

8.48

Over-Ranged

(>32 M ohm)
Over-Ranged (>32 M ohm)

\section{Comments}

The relatively consistent readings, although greater than 0.6 $\mathrm{M} \Omega$, indicate the probe is operating. 
WSRC-TR-98-00408

Revision 0

Page 9 of 16

November 12, 1998

Table 3. Results of Gilsulate-Simulated High Level Waste Salt Solution Conductivity Probe Tests Using the Multimeter

\begin{tabular}{|c|c|c|c|c|}
\hline \multicolumn{4}{|c|}{ Resistance (M-ohms) } & \multirow[b]{2}{*}{ Comments } \\
\hline$\underline{\text { Solution }}$ & Tip & End & Notch & \\
\hline $\begin{array}{c}9.6 \mathrm{M} \mathrm{Na}^{+} \\
\text {(no Gilsulate) }\end{array}$ & 0.217 & 0.144 & 0.091 & \\
\hline $\begin{array}{c}9.6 \mathrm{M} \mathrm{Na}^{+} \\
\text {(with } 0.00011 \mathrm{~g} / \mathrm{cm}^{2} \\
\text { Gilsulate) }\end{array}$ & 0.692 & 0.753 & 0.647 & $\begin{array}{l}\text { solution tests are } \\
\text { considerably less } \\
\text { than those for the } \\
\text { tap water cases. } \\
\text { The relatively }\end{array}$ \\
\hline $\begin{array}{c}9.6 \mathrm{M} \mathrm{Na}^{+} \\
\text {(with } 0.00044 \mathrm{~g} / \mathrm{cm}^{2} \\
\text { Gilsulate) }\end{array}$ & 0.721 & 0.794 & 0.823 & $\begin{array}{c}\text { consistent readings } \\
\text { indicates that the } \\
\text { probe is } \\
\text { functioning }\end{array}$ \\
\hline $\begin{array}{c}9.6 \mathrm{M} \mathrm{Na}^{+} \\
\text {(with } 0.00087 \mathrm{~g} / \mathrm{cm}^{2} \\
\text { Gilsulate) }\end{array}$ & 0.884 & 0.921 & 0.930 & $\begin{array}{l}\text { properly in these } \\
\text { tests. }\end{array}$ \\
\hline $\begin{array}{c}9.6 \mathrm{M} \mathrm{Na}^{+} \\
\text {(with } 0.0042 \mathrm{~g} / \mathrm{cm}^{2} \\
\text { Gilsulate) }\end{array}$ & 0.782 & 0.828 & 0.902 & \\
\hline $\begin{array}{c}9.6 \mathrm{M} \mathrm{Na}^{+} \\
\text {(with } 0.0084 \mathrm{~g} / \mathrm{cm}^{2} \\
\text { Gilsulate) }\end{array}$ & 0.848 & 0.865 & 0.930 & \\
\hline $\begin{array}{c}9.6 \mathrm{M} \mathrm{Na}^{+} \\
\text {(with } 0.042 \mathrm{~g} / \mathrm{cm}^{2} \\
\text { Gilsulate) }\end{array}$ & $\begin{array}{c}\text { Over-Ranged } \\
(>32 \mathrm{M} \Omega) \\
\text { All repetitions } \\
\text { gave same } \\
\text { result }\end{array}$ & $\begin{array}{c}\text { Over-Ranged } \\
(>32 \mathrm{M} \Omega) \\
\text { Repetitions gave } \\
1.1-3.0 \mathrm{M} \Omega\end{array}$ & $\begin{array}{l}\text { Over-Ranged } \\
(>32 \mathrm{M} \Omega) \\
\text { After a few } \\
\text { minutes this } \\
\text { became } \\
0.784, \\
\text { repetitions } \\
\text { gave } 1.3- \\
2.3 \mathrm{M} \Omega\end{array}$ & $\begin{array}{l}\text { The erratic } \\
\text { readings, including } \\
\text { several that are } \\
\text { over-ranged } \\
\text { indicate that the } \\
\text { Gilsulate is } \\
\text { interfering with the } \\
\text { operation of the } \\
\text { probe. }\end{array}$ \\
\hline $\begin{array}{c}9.6 \mathrm{M} \mathrm{Na}^{+} \\
\text {(with } 0.084 / \mathrm{cm}^{2} \\
\text { Gilsulate) }\end{array}$ & $\begin{array}{c}\text { Over-Ranged } \\
(>32 \mathrm{M} \Omega) \\
\text { Repetitions } \\
\text { gave } 0.11 \text { to } \\
1.5 \mathrm{M} \Omega .\end{array}$ & $\begin{array}{c}22.1 \\
\text { Repetitions gave } \\
0.13 \text { to } 1.6 \mathrm{M}\end{array}$ & $\begin{array}{c}1.05 \\
\text { Repetitions } \\
\text { gave } 0.17 \text { to } \\
1.4 \mathrm{M} \Omega\end{array}$ & \\
\hline
\end{tabular}


Because earlier testing using the multimeter was inconclusive, the remaining tests were performed using the Gempack circuit. Results from both sets of tests are reported, but the Gempack results are considered more reliable. The Gempack tests started indicating problems with $\sim 0.004 \mathrm{~g} / \mathrm{cm}^{2}$ of Gilsulate added to the surface with the tip just touching the Tank $43 \mathrm{H}$ solution surface. When the probe was lowered to $1 / 8$ inch depth the probe functioned properly. At higher Gilsulate levels (up to $0.05 \mathrm{~g} / \mathrm{cm}^{2}$ ) the probe would not function up to a depth of $1 / 8$ inch, but did resume operation at a depth of $3 / 4$ inch. Table 4 gives the results of Gilsulate-Water and Gilsulate-Tank $43 \mathrm{H}$ Salt Solution tests conducted using the Gempack circuit. In these tests the hydrophobic Gilsulate tended to coat the conductivity probe as it was lowered. Figure 6 demonstrates this effect. Eventually, as the depth increased, it appeared that holes opened in the Gilsulate coating which apparently allowed the aqueous phase to contact the probe. Figure 7 shows one of thes holes. Because of the nature of Gilsulate in contact with an aqueous phase and variations in surface coverage, test results were inconsistent and it was difficult to determine a cutoff level at which Gilsulate becomes a problem. Operability of the probe depends strongly on whether there is a high level of Gilsulate in the neighborhood of the probe.

Table 4. Results of Gisulate Conductivity Probe Tests Using the Gempack Circuit

\begin{tabular}{|c|c|c|c|c|c|c|}
\hline \multirow{2}{*}{$\begin{array}{l}\text { Gilsulate } \\
\text { Added }\end{array}$} & \multicolumn{3}{|c|}{$\begin{array}{c}\text { Tap Water Tests } \\
\text { (Positive Test }- \text { Y/N) }\end{array}$} & \multicolumn{3}{|c|}{$\begin{array}{c}\text { Tank 43H Solution Tests } \\
\text { (Positive Test }- \text { Y/N) }\end{array}$} \\
\hline & Tip & $\underline{\text { End }}$ & Notch & $\underline{\text { Tip }}$ & End & Notch \\
\hline None & Y & $Y$ & $\mathrm{Y}$ & $\mathrm{Y}$ & $Y$ & $\mathrm{Y}$ \\
\hline $9 \mathrm{E}-5 \mathrm{~g} / \mathrm{cm}^{2}$ & $\mathrm{Y}$ & $Y$ & $\mathrm{Y}$ & $\mathrm{Y}$ & $\mathrm{Y}$ & $\mathrm{Y}$ \\
\hline $4 \mathrm{E}-4 \mathrm{~g} / \mathrm{cm}^{2}$ & $Y$ & $Y$ & $\mathrm{Y}$ & $\mathrm{Y}$ & $Y$ & $\mathrm{Y}$ \\
\hline $8 \mathrm{E}-4 \mathrm{~g} / \mathrm{cm}^{2}$ & $\mathrm{Y}$ & $\mathrm{Y}$ & $\mathrm{Y}$ & $\mathrm{Y}$ & $\mathrm{Y}$ & $Y$. \\
\hline $0.004 \mathrm{~g} / \mathrm{cm}^{2}$ & $\mathrm{Y}$ & $\mathrm{Y}$ & $Y$ & $\mathrm{~N}$ & $\mathrm{Y}$ & $\mathrm{Y}$ \\
\hline $0.008 \mathrm{~g} / \mathrm{cm}^{2}$ & $\mathrm{~N}$ & $\mathrm{~N}$ & Y & $\mathrm{Y}$ & $\mathrm{Y}$ & Y \\
\hline $0.05 \mathrm{~g} / \mathrm{cm}^{2}$ & $N$ & $\mathrm{~N}$ & $Y$ & $\mathrm{~N}$ & $\mathrm{~N}$ & $\mathrm{Y}$ \\
\hline
\end{tabular}

Figure 6. Gilsulate Coating Probe

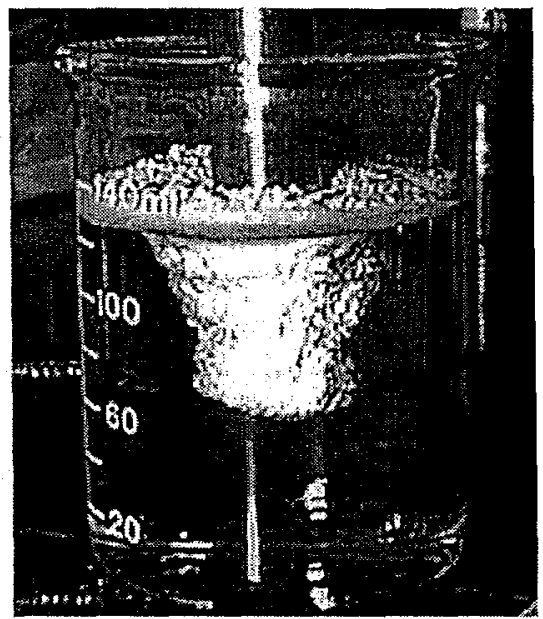


Figure 7. Hole in Gilsulate Layer

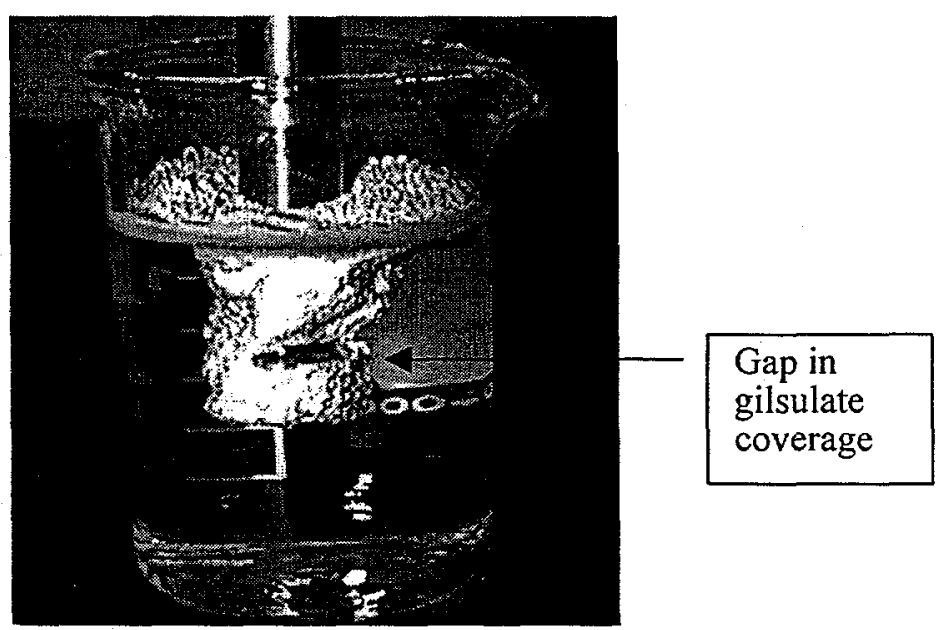

\section{Dow Corning $\mathrm{H}-10$ Tests}

Dow Corning H-10 is used in the HLW evaporator systems to control foaming. When Dow Corning. $\mathrm{H}-10$ was added to water, it appeared to dissolve in the water and not collect on top. Solids from the Dow Corning H-10 collected at the surface when it was added to the top of the Tank $43 \mathrm{H}$ salt solution described in Table 1. Figure 8 shows the Dow Corning H-10 solids collecting in a layer at the surface. In neither case did the Dow Corning $\mathrm{H}-10$ affect the operation of the conductivity probe with the Gempack circuit. Table 5 shows the results of the conductivity probe Gempack tests with Dow Corning $\mathrm{H}-10$.

Figure 8. Dow Corning H-10 Solids at Surface of Salt Solution.

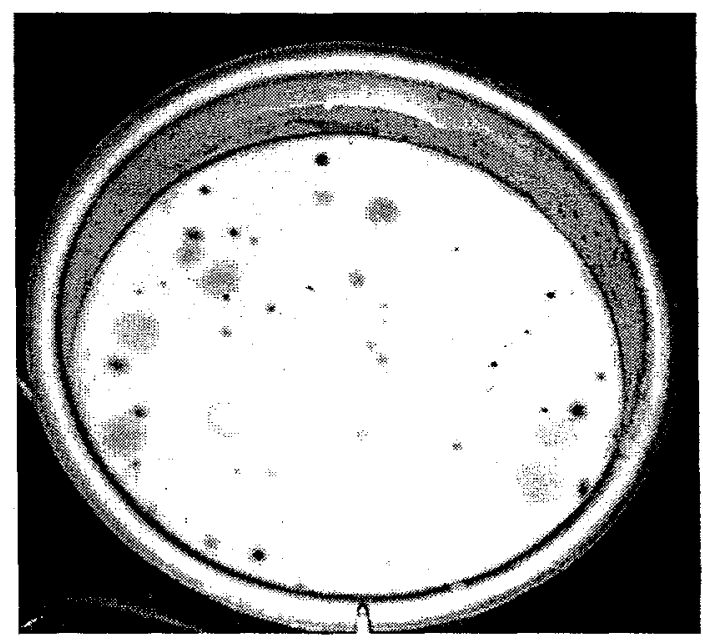


Table 5. Results of Dow Corning H-10 Conductivity Probe Tests Using the Gempack Circuit

\begin{tabular}{|c|c|c|c|c|c|c|}
\hline $\begin{array}{c}\text { Average } \\
\text { Depth (mm) }\end{array}$ & & $\begin{array}{l}\text { Vater } \\
\text { e Tes }\end{array}$ & & & $\begin{array}{l}\text { I Solu } \\
\text { e Test }\end{array}$ & \\
\hline H-10 Added & Tip & End & Notch & Tip & End & Notch \\
\hline None & $\mathrm{Y}$ & $\mathrm{Y}$ & $Y$ & $\mathrm{Y}$ & $Y$ & $\mathrm{Y}$ \\
\hline 0.0017 & $\mathrm{Y}$ & $\mathrm{Y}$ & Y & Y & Y & $\mathrm{Y}$ \\
\hline 0.017 & Y & $\mathrm{Y}$ & $Y$ & $\mathrm{Y}$ & $\mathrm{Y}$ & $\mathrm{Y}$ \\
\hline 0.17 & $\mathrm{Y}$ & $\mathrm{Y}$ & $Y$ & $\mathrm{Y}$ & $\mathrm{Y}$ & $\mathrm{Y}$ \\
\hline 1.7 & $\mathrm{Y}$ & $\mathrm{Y}$ & $\mathrm{Y}$ & $\mathrm{Y}$ & Y & $\mathrm{Y}$ \\
\hline Dow Corning & atifo & & & & & \\
\hline $\begin{array}{l}\text { Dow Corning } \\
\text { Figure } 9 \text { show } \\
\text { not interfere } \\
\text { function when } \\
\text { the liquid. At } \\
\text { depth of up to } \\
\text { the apparent } r \\
\text { Dow Corning }\end{array}$ & $\begin{array}{l}\text { ntifo } \\
\text { Dow } \\
\text { e ope } \\
\text { the t } \\
\text { knes } \\
\text { ch. } \\
\text { for n }\end{array}$ & $\begin{array}{l}\text { ted or } \\
544 \mathrm{~A} \\
\text { the co } \\
\text { ed the } \\
\text { im of } \\
\text { intifoa } \\
\text { ining. }\end{array}$ & $\begin{array}{l}\text { face of } t \\
\text { At thicl } \\
\text { ty probe } \\
\text { put did re } \\
\text { foam, th } \\
\text { d the pro } \\
\text { gives th }\end{array}$ & $\begin{array}{l}\text { olution } \\
\text { up to } \\
\text { hickn } \\
\text { hen th } \\
\text { did no } \\
\text { high }\end{array}$ & $\begin{array}{l}\text { mbled } \\
\text {, the } 5 \\
\text { mm, } \\
\text { was lo } \\
\text { at all } \\
\text { of addi } \\
\text { ivity }\end{array}$ & $\begin{array}{l}\text { led greas } \\
\text { foam did } \\
\text { e did not } \\
\text { urther int } \\
\text { owered to } \\
\text { d that wa } \\
\text { ts with }\end{array}$ \\
\hline
\end{tabular}

Figure 9. Dow Corning 544 Antifoam.

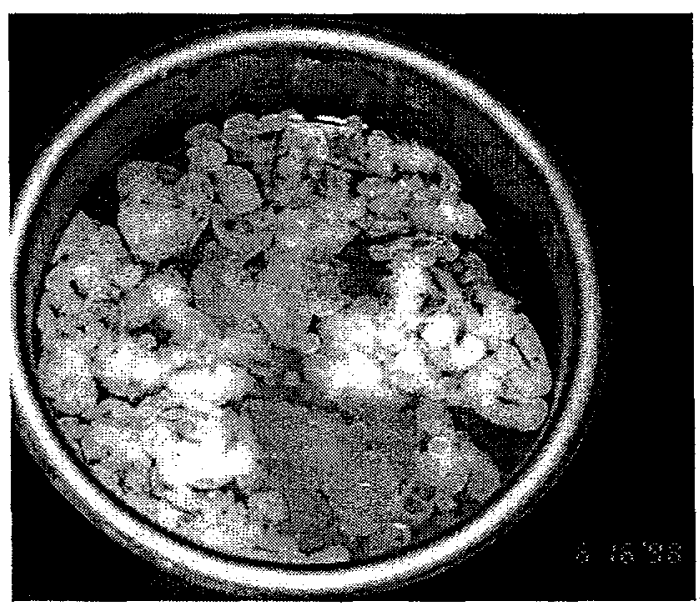


Table 6. Results of Dow Corning 544 Antifoam Conductivity Probe Tests Using the Gempack Circuit

Average Depth (mm) Dow Corning H-10 Added

None

0.0015

0.016

0.17

1.8
Tip

$\mathrm{Y}$

Y

Y

$\mathrm{N}$

$\mathrm{N}$
End

Y

Y

Y

$\mathrm{Y} / \mathrm{N}$

$\mathrm{N}$

\section{Notch}

Y

Y

Y

Y

$\mathrm{N}$

\section{TBP/n-Paraffin Tests}

When a mixture of $30 \%$ TBP and $70 \%$ n-paraffin was added to the top of the salt solution, it remained on the surface. No affect was observed on the operation of the conductivity probe at average organic depths up to $0.17 \mathrm{~mm}$. At an average depth of $1.6 \mathrm{~mm}$ of the mixture, the probe did not register when the tip contacted the surface of the liquid, but the probe did respond as it was lowered further into the liquid. At an average depth of $3.3 \mathrm{~mm}$ of the mixture, the probe did not respond when initially contacted with the liquid or when lowered to a depth of $\sim 1 / 8$ inch. However, when the probe was lowered to a depth of $\sim 3 / 4$ inch, so that the tip of the probe was below the organic mixture, it did give a positive reading on the Gempack circuit. The results of the TBP-n-paraffin tests are given in Table 7.

Table 7. Results of Tri-n-butyl Phosphate/n-Paraffin Conductivity Probe Tests Using the Gempack Circuit

Average Depth (mm)

TBP/n-Paraffin Added

None

0.0017

0.017

0.17

1.7

3.3
Tip

Y

Y

Y

Y

$\mathrm{N}$

$\mathrm{N}$
End

$\mathrm{Y}$

Y

Y

Y

Y

$\mathrm{N}$
Notch

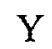

Y

Y

Y

Y

Y 


\section{$\underline{\text { Sodium Aluminum Silicate Tests }}$}

HLWME personnel noticed that Gilsulate was largely composed of a material similar to the sodium aluminum silicate material that was found to be crystallizing out in the gravity drain lines. Since the Gilsulate was known to be hydrophobic and therefore interfere with the operation of the conductivity probes, a concern was raised that sodium aluminum silicate material might cause the same problem. In a telephone discussion, Bruce McEntyre of American Thermal Products, Inc., indicated that the hydrophobicity of Gilsulate was due to the addition of two proprietary coatings, not to the sodium potassium aluminum silicate material. It was this hydrophobicity which was apparently responsible for the Gilsulate interfering with the conductivity probe operation, and therefore the sodium aluminum silicate material which crystallizes in the gravity drain lines is not expected to interfere in the same way.

However, researchers were concerned that the sodium aluminum silicate could crystallize onto the probe or the sides of the leak collection box and in that way interfere with the operation of the probe. A couple of tests were run where sodium aluminum silicate was crystallized, but it all precipitated to the bottom of the vessel and therefore did not interfere with the operation of the probe. Measurements of the conductivity probe using the multimeter gave results which similar to readings determined with salt solutions containing no organic or Gilsulate. Therefore, for these tests it was concluded that there was no interference with the operation of the conductivity probe. Table 8 gives the results of the tests for sodium aluminum silicate material.

Table 8. Results of Sodium Aluminum Silicate Conductivity Probe Tests Using the Multimeter

Solution

$$
3 \mathrm{M} \mathrm{Na}^{+} \text {Salt }
$$

Solution with

Sodium Aluminum

Silicate

$10 \mathrm{M} \mathrm{Na}^{+}$Salt

Solution with

Sodium Aluminum

Silicate
Tip

$0.450-0.811$

$0.479-0.524$
$0.129-0.419$

Notch

$0.726-0.931$

$0.583-0.875$

$0.130-0.406$
Resistance (M-ohms)

End 


\section{CONCLUSIONS}

Gilsulate can interfere with the operation of the conductivity level probes in sufficient quantity. The Gilsulate coats the probe as it enters the water and can prevent contact of the probe with the aqueous phase. Quantification of this effect is difficult, since the Gilsulate does not distribute evenly over the surface and also may or may not completely coat the probe. Incomplete coating of the probe allows it to operate. Because operation of the probe in the presence of Gilsulate may be affected by factors which cannot be controlled, it is recommended that no Gilsulate be allowed in the leak detection boxes.

Sodium aluminum silicate compounds, which have been found to crystallize in Tank Farm gravity drain lines and which are similar to a major constituent of Gilsulate, are not hydrophobic and therefore do not interfere with operation of the conductivity probes in the same way that Gilsulate does. However, the sodium aluminum silicate compounds could crystallize on the probe or the sides of the leak detection box. Our testing was unable to produce this result, though other work has indicated that it does occur. Since the crystals produced in these tests precipitated to the bottom of the vessel, there was no effect on the operation of the probe.

Dow Corning H-10 Emulsion was found not to interfere with the operation of the conductivity probe in any quantity tested. Dow Corning 544 Antifoam did interfere with operation of the probe in large quantity, and therefore its presence in the leak collection boxes should be avoided. It is doubtful, however, that the large antifoam concentrations used in the test would be experienced in normal operation.

The TBP/n-paraffin mixture interfered with the operation of the probe only to the extent that the organic mixture was not detected by the probe. The aqueous phase was still detected when it contacted the probe. The TBP/n-paraffin mixture did not coat the probe and interfere with operation as did the Gilsulate and the Dow Corning 544 Antifoam.

\section{QUALITY ASSURANCE}

The work documented herein was requested in Reference 1. Since these are scoping studies, no task technical plan or quality assurance plan were written for this work. The salt solutions prepared for this work are documented in WSRC-NB-97-00493. The conductivity probe tests are documented in WSRCNB-95-154.

\section{REFERENCE}

1. G. A. Taylor, “Conductivity Probe Conductivity”, HLE-TTR-98018, November 19, 1997. 
WSRC-TR-98-00408

Page 16 of 16

Revision 0

November 12, 1998

APPROVALS

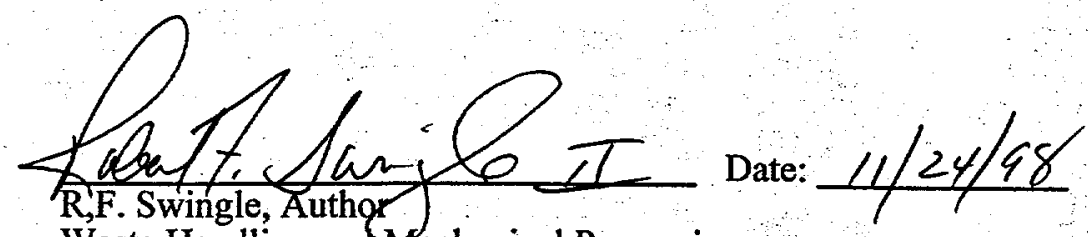

Waste Handling and Mechanical Processing

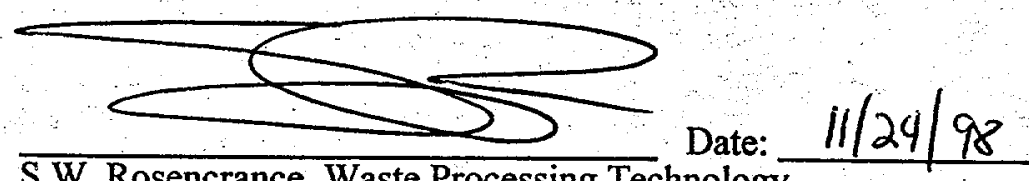

S.W. Rosencrance, Waste Processing Technology

Design Check per Manual E7, Procedure 2.40

W.B. Van feet

Date: $11 / 24 / 98$

W. B. Van Pelt, Manager,

Waste Handling and Mechanical Processing

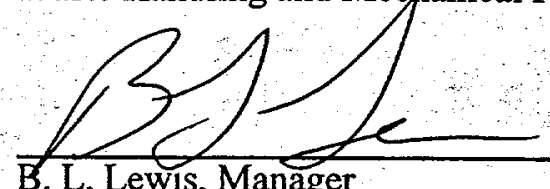

Dat: $121 / 2 / 98$

Concentration, Storage and Transfer Engineering

W id Twodecel Dat:

W. L. Tamosaitis, Manager

Waste Processing Technology

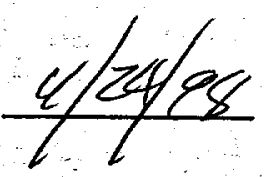




\section{Distribution}

T. M. Monahan, 703-H

V. G. Dickert, 703-H

M. J. Barnes, 773-A

T. E. Britt, 703-H

W. C. Clark, 704-56H

S. D. Fink, 773-A

D. T. Hobbs, 773-A

R. A. Jacobs, 704-T

M. D. Johnson, 703-H

M. T. Keefer, 704-56H

T. J. Lex, 703-H

B. L. Lewis, 703-H

M. S. Miller, 704-56H

M. J. Montini, 704-56H

J. P. Morin, 703-H

C. A. Nash, 773-43A

J. K. Norkus, 992-3W

L. M. Papouchado, 773-A

R. A. Peterson, 773-A

S. F. Piccolo, 703-3N

M. R. Poirier, 679-T

P. L. Rutland, 241-152H

P. C. Suggs, 703-H

R. F. Swingle, 773-A

W. L. Tamosaitis, 773-A

G. A. Taylor, 703-H

T. C. Temple, 703-H

J. K. Thomas, 992-3W

W. B. Van Pelt, 773-43A

D. D. Walker, 773-A

W. R. Wilmarth, 773-42A

G. T. Wright, 773-A

LWP Files c/o C. Canada, 773-A

STI, 703-43A

W. F. Bates, 707-H

R. L. Salizzoni, 707-H

G. D. Thaxton, 703-H

M. H. Layton, 703-H

B. J. Shapiro, 703-H

S. A. Saunders, 705-C

C. A. Roach, 705-C

F. G. McNatt, 704-8H 